\title{
Cancer related fatigue syndrome in neoplastic diseases
}

\author{
Magdalena Franc ${ }^{1}$, Bogdan Michalski ${ }^{2}$, Ilona Kuczerawy ${ }^{1}$, Justyna Szuta ${ }^{1}$, Violetta Skrzypulec-Plinta ${ }^{3}$ \\ ${ }^{1}$ Doctor Studies, Medical Department, Silesia Medical University, Katowice, Poland \\ ${ }^{2}$ Department of Gynecological Oncology, Women School of Health, Silesia Medical University, Katowice, Poland \\ ${ }^{3}$ Department of Woman School of Health, Silesia Medical University, Katowice, Poland
}

\begin{abstract}
Fatigue is one of the most important factors which has a considerable influence on treatment and the life quality of oncological patients. The fatigue syndrome is often diagnosed during cancer treatment and this syndrome is not related to the physical effort. Cancer related fatigue is a patient's subjective, psychologically, physically and emotionally based feeling. It is disproportionate to patient's daily activity. The pathogenesis of this syndrome remains still unknown. However, on the basis of various questionnaires, it is possible to test the disease's complex nature. Cancer related fatigue causes deterioration of patient's life along with lower motivation to struggle with the disease. It is thought that the factor which increases the incidence of cancer related fatigue is a long-term use of drugs such as opioids, benzodiazepine, and medicines containing codeine, tranquilizers, anxiolytics and antidepressants. On the basis of the results, one can choose an appropriate treatment method for cancer related fatigue such as rehabilitation, psychotherapy or public assistance. A great number of patients consider excessive fatigue a typical concomitant symptom in neoplastic disease; therefore, they do not report it. It is of a paramount importance to make patients aware of the fact that cancer related fatigue is a serious disease which can be treated.
\end{abstract}

Key words: fatigue, cancer disease, fatigue-related syndrome, oncology.

\section{Introduction}

One of the major problems concerning people suffering from neoplastic diseases is the struggle with the disease and overwhelming treatment. The very information about a neoplastic disease causes patients' negative emotions. It results in a defensive reaction in the form of denial, diagnosis denial and isolating from the environment. Patients often become aggressive and they totally change their behaviour. Unfortunately, it causes certain difficulties during treatment [1].

Fatigue, which is a result of a neoplastic disease, also constitutes a difficulty. It is so-called cancer related fatigue (CRF) [2-4].

We can define the fatigue as "a subjective feeling of the energy lack to commence or sustain any activity, which feeling is not related to depression or decreased muscle power" $[5,6]$. Pyk et al. define fatigue as "the intermediary and reversible state of the organism's efficiency decrease resulting from the work done. There are objective physiological changes coexisting such as blood chemistry, ECC, pulse, skin conductance and subjective changes such as fatigue, lesser work involvement" [1].

The European Organization for Research and Treatment of Cancer (EORTC) defines fatigue as a "subjec- tive feeling of fatigue, weakness and lack of energy" $[3,7-9]$

The main symptoms of CRF are the feeling of both physical and emotional exhaustion, fatigue, which is disproportionate to the task done. It impedes daily routines. CRF is classified at World Health Organization's ICD-10-CM under the symbol G $93.3[2,10]$.

Disorders which may result from fatigue may concern the whole organism or its parts. Fatigue may be divided into:

- physical,

- psychological, and

- psycho-nervous one [1].

If a disorder is caused by the damage of a neural conduction tract, it may result in pathological fatigue, namely, the feeling of excessive effort and fatigue. The psychological fatigue is, on the other hand, manifested by a limited concentration and endurance of mental activities [5].

It may be divided into:

- acute and moderate fatigue, which constitutes the organism's defensive reactions,

- chronic fatigue, which is a symptom of an illness [1].

Fatigability often appears before a diagnosis and increases during treatment - it remains after the end of 
therapy. It decreases patients' life quality, both in the physical and psychological sphere [2, 7, 11-14].

\section{Incidence}

According to various sources, during neoplastic disease, fatigue is felt by $70-100 \%$ of patients $[2,10,12$, 14-18], including the half of the patients during chemotherapy (according to Huang Xu et al., it constitutes 80$96 \%$ of patients) and 60-93\% during radiotherapy [19]. From the research conducted by Pyk, Michno et al., it may be concluded that the patients often report fatigue on admission to the hospital (53\% of the examined patients) [1].

Fatigability is more often felt by women and people who were diagnosed with metastases [2]. This symptom is reported by $70 \%$ of people suffering from lung neoplasm [20].

\section{Symptoms}

Cancer related fatigue is a subjective psychologically, physically and emotionally based feeling; it is disproportionate to patient's daily activity $[4,12,17,19,21]$.

Chronic fatigue syndrome differs from fatigue, which results from the physical effort. This difference stems from the fact that it is not related to rest [15].

Patients suffering from the chronic fatigue syndrome are diagnosed as having pains and muscle weakness, headaches, throat aches, weakness and lack of appetite, increased perspiration, especially at night, lymphatic nodes tenderness, sight disorder, sleep disorder and slightly increased body temperature [5, 6, 8, 9, 22, 23].

During chemotherapy, women experienced fatigue which was accompanied by a mood deterioration and emotional stress [7, 24]. Other authors observe that there are difficulties concerning concentration, memory problems, easy fatigability, lack of strength to start new things, which all posed no problems before [5].

Fatigue experienced by female patients, who were treated for a breast cancer, is more frequent than the one experienced by people who did not have a breast cancer. Women, aged between 30 and 50, suffer most often from fatigue [5]. It may result from the earlier and violent menopause which stems from chemotherapy and hormone therapy [19]. The symptoms of chronic fatigue syndrome remain more than 6 months and are not the symptoms of the underlying disease [6].

\section{Diagnosis and fatigue assessment}

A number of diseases manifest themselves in $\mathrm{fa}$ tigue, e.g. neurological diseases, cardiovascular and blood diseases, neoplastic disease, endocrinological and psychiatric disorders [5]. Therefore, the diagnostic procedure of the chronic fatigue syndrome has a considerable significance for choosing appropriate treatment. Cancer related fatigue is described as a complex, psychologically, physically and emotionally based feeling. The standard of living has a great influence on CRF [3, 7-9, 15, 24-26].

However, fatigue as a symptom is quite often underestimated. Chronic fatigue causes patients' deterioration of life; moreover, it results in the decrease of the motivation to struggle with the disease [16, 19, 20, 27].

The diagnostic procedures, depending on a suspicion concerning the cause of disorder, use magnetic resonance, PET, electrophysiological and biochemical tests, muscle biopsy, and neuropsychological tests. Examining fatigue is difficult to carry out owing to the fact that it is of a subjective nature. Despite the abovementioned diagnostic procedures, fatigue assessment scales are used [5].

Questionnaires, which examine the physical, emotional and cognitive aspects of fatigue, turn out to be useful. The aforementioned questionnaires, to name a few, are Brief Fatigue Inventory (BFI), Multidimensional Fatigue Inventory (MFI-20), which determines the dimensions of fatigue such as general fatigue, physical one, decreased activeness, motivation and psychological fatigue [4, 24], the Rotterdam Symptom Checklist (RSCL) $[2,5]$, and the Functional Assessment of Cancer Therapy-Fatigue Scale (FACT-F) [2, 12, 28].

The intensity of fatigue can be examined by means of a Verbal Rating Scale (VRS), Visual Analogue Scale (VAS) and Numerical Rating Scale (NRS) of the Linear Analogue Scale Assessment (Fig. 1).

\section{Fatigue Verbal Rating Scale}

Do you feel fatigue today?

Not at all A little Quite Very much

\section{Fatigue Visual Analogue Scale}

Do you feel fatigue today?

$\begin{array}{cc}\begin{array}{c}\text { Do not } \\ \text { feel fatigue }\end{array} & \text { I feel } \\ \text { fatigue to } \\ \text { a considerable } \\ \text { degree }\end{array}$

Fatigue Numerical Rating Scale

Please assess the intensity of fatigue on a provided line, marking the place which is the closest to your fatigue during last 24 hours.

$\begin{array}{ccccccccccc}\begin{array}{cccccc}0 \\ \text { No fatigue }\end{array} & & & & & & & & 9 & 10 \\ \text { Maximum fatigue }\end{array}$

Fig. 1. The scale assessing the intensity of fatigue [35] 
Additionally, of a great value there are interview and physical examinations, information which can be obtained from the family. On account of the fact that patients commencing oncological treatment suffer from fatigue, it is essential to start the therapy at the very beginning of treatment [2]. Unfortunately, the very mechanism of chronic fatigue syndrome formation remains unknown for the patients suffering it $[2,5,29]$. Nevertheless, it is sure that it may intensify during treatment and the progression of the disease [2].

While diagnosing the chronic fatigue syndrome, it is significant to exclude the beginning depression. The symptoms of depression may include fatigue and, additionally, low self-esteem and motivation, bad mood, the feeling of guilt and isolation [9].

\section{Causes}

The pathogenesis of chronic fatigue still needs examination and research. It is believed that fatigue may result from such factors as:

- properly functioning hypothalamic-pituitary-adrenal axis, which "guarantees the balance of the organism and allows to quickly react to stress",

- immunological system's disorders caused by inflammatory reactions mediators (directly) or by the influence on hypothalamic-pituitary-adrenal axis (indirectly),

- the decrease in neurotransmitters' level such as noradrenaline and serotonin,

- "lactic acid poisoning resulting from the metabolism in muscles,

- oxygen debt caused by the blood level drop in blood" $[1,2,5,7,8,13,25]$.

The factor which increases the incidence of CRF is lengthy administration of medicines such as opioids, benzodiazepine, and medicines containing codeine, tranquilizers, anxiolytics and antidepressants [5].

It is considered that fatigability can be influenced by such factors as diurnal rhythm distortion, skeletal muscles cachexia or proinflammatory cytokines production $[2,13]$.

Moreover, smoking is considered to influence psychological fatigue in oncological patients who suffer from a lung cancer [20].

Fatigue can be intensified by various factors such as "pain, emotional pain, sleeping disorders, anaemia, eating disorders, the level of activity, side effects of medicines (e.g. cardiac drugs - beta blockers) or a concomitant disease" [2].

Patients treated oncologically take steroids what results in body weight fluctuations. This, on the hand, leads to taking up various diets in order to decrease body weight - it mainly concerns women. One of the examples is women during radiotherapy who suffer from breast cancer or gynaecologic neoplasms. They, at all costs, try to keep their weight on the same level claiming that they want to fit the mask. Such diet disorders favour the chronic fatigue syndrome. It is of a great help to recommend accurate physical activity to them which is adequate to their health and abilities.

Yet other drugs which intensify fatigability are antiemetic medicines and tranquillizers [2].

\section{Treatment}

During CRF treatment, there is a great need to pay attention to patient's lifestyle and physical activity adequate to their abilities. What is more, appropriate rehabilitation is crucial and so is psychotherapy (Cognitive Behavioural Therapy - CBT) and public assistance $[5,11,12,17,30]$.

Preventing, as well as the treatment of CRF, is mainly based on patient and family education, appropriate psycho- and physiotherapy, sleeping disorder therapy and proper diet education during and after treatment; moreover, pharmacological treatment is used $[2,7,14,19,31]$.

Psychotherapy uses cognitive and behavioural therapy which can be conducted individually with the patient, in a group; it is also a marital or family therapy. Therapists help patients trigger changes in thinking, feeling and their behaviour. The aim and course of the therapy is at the very beginning consulted and agreed by a therapist together with a patient [23].

Regular exercises which decrease fatigue, depression and anxiety are of a great help. These exercises are best done during treatment and after it. Fatigue is less frequently observed in those patients who are undergoing hormone therapy [19].

The study concerning the influence of rehabilitation on the level of patients' fatigue after oncological treatment was conducted by Weert et al. The exercises were selected on the individual basis using aerobic training and exercises involving torso and limbs. Patients, who accomplished rehabilitation, were diagnosed as experiencing less physical and psychological fatigue. A similar study was conducted by Adamsen et al. who examined a group of patients undergoing chemotherapy. This study used physical exercises, relaxation and massage. It was proved that the physical efficiency and patients' activeness increased [10].

Patients with CRF suffering from Hodgkin's disease after chemotherapy were diagnosed as having better mood and weakened symptoms of CRF within five months after chemotherapy [29].

There is also a theory of "six E's" by Portney from the Beth Israel Medical Center in New York. Six E's stand for: education, energy conservation, exercise, energy restoration, easing stress and eating well [10, 32-34]. 
Pharmacological treatment reduces the main symptoms connected with chemotherapy, namely, nausea, vomiting and blood parameters [29].

Unfortunately, a significant barrier in diagnosing the disease is the fact that patients attribute excessive fatigue to a basic symptom as a concomitant symptom, especially during neoplastic disease. They are afraid of stopping oncological treatment. Owing to this fact, they do not report this symptom to a doctor [5].

\section{Conclusions}

All patients who were treated oncologically suffer, during neoplastic disease, from fatigue which may transform itself imperceptibly into CRF. There is a number of attempts made to diagnose and treat this disease; however, if we do not know the pathogenesis, we cannot observe at early stages first symptoms to prevent this disease.

Therefore, further research is essential thanks to which the origin of fatigue would be determined. Owing to this fact, it would be possible to appropriately prevent it, which would result in improving patients' lives during treatment and after it.

\section{Disclosure}

\section{Authors report no conflict of interest.}

\section{References}

1. Pyk M, Michno M, Nowak-Szymańska M. Zmęczenie, ból, lęk i depresja u chorych onkologicznych. Studia Medyczne Akademii Świętokrzyskiej 2003; 1: 149-158.

2. Zaucha M. Wpływ niedokrwistości na jakość życia chorych na nowotwory. Akademia Onkologii i Hematologii. Program edukacyjny pod patronatem PTHiT oraz PTOK.

3. Centeno C, Angustias Portela Tejedor M, Carvajal A, et al. What is the best term in Spanish to express the concept of cancer-related fatigue? J Palliat Med 2009; 12: 441-445.

4. Lin J-M, Brimmer DJ, Maloney EM, et al. Further validation of the Multidimensional Fatigue Inventory in a US adult population sample. Popul Health Metr 2009; 7: 18

5. Brola W, Ziomek M, Czernicki J. Zespół zmęczenia w przewlekłych chorobach neurologicznych. Neurol Neurochir Pol 2007; 41: 340-349.

6. Jorgensen R. Chronic fatigue: an evolutionary concept analysis. J Adv Nurs 2008; 63: 199-207.

7. Barsevick A, Frost M, Zwinderman A, et al.; GENEQOL Consortium. I'm so tired: biological and genetic mechanisms of cancer-related fatigue. Qual Life Res 2010; 19: 1419-1427.

8. Hauser K, Rybicki L, Walsh D. What's in a Name? Word descriptors of cancer-related fatigue. Palliat Med 2010; 24: 724-730.

9. Karakan S, Sezer S, Ozdemir FN. Factors related to fatigue and subgroups of fatigue in patients with end-stage renal disease. Clin Nephro 2011; 76: 358-364.

10. Pyszora A. Efektywność fizjoterapii stosowanej u pacjentów cierpiących z powodu zmęczenia związanego z chorobą nowotworową. Medycyna Paliatywna w Praktyce 2008; 2: 164-168.

11. Wanchai A, Armer JM, Stewart BR. Nonpharmacologic supportive strategies to promote quality of lefe in patients experiencing cancer-related fatigue: a systematic review. Clin J Oncol Nurs 2011; 15: 203-214.
12. de Oliviera Campos MP, Riechelmann R, Martins LC, et al. Guarana (Paullinia cupana) improve fatigue in breast cancer patients undergoing systemic chemotherapy. J Altern Complement Med 2011; 17: 505-512.

13. Spratt DE, Mayuko S, Riaz N, et al. Time course and predictors for cancer-related fatigue in a series of oropharyngeal cancer patints treated with chemoradiation therapy. Oncologist 2012; 17: 569-576.

14. Engelke Z. Patient Education: Taching Patients about Long-Term Effects of Chemotherapy. Cinahl Information System, 2012.

15. Yennurajalingam S, Palmer JL, Chacko R, et al. Factors associated with response to methylphenidate in advanced cancer patients. Oncologist 2011; 16: 246-253.

16. Radbruch L, Strasser F, Elsner F, et al. Research Steering Committee of the European Association for Palliative Care (EAPC). Fatigie in palliative care patients - an EAPC approach. Palliat Med 2008; 22: 13-32.

17. Johnson RL, Block I, Gold MA, et al. Effect of methylphenidate on fatigue in women with recurrent gynecologic cancer. Psychooncology 2010; 19 : 955-958.

18. Borneman T, Koczywas M, Sun V, et al. Effectiveness of a clinical invention to eliminate barriers to pain and fatigue management in oncology. J Palliat Med 2011; 14: 197-205.

19. Huang Xu, Zhang Q, Kang X, et al. Factors associated with cancer-related fatigue in breast cancer patients undergoing endocrine therapy in an urban setting: a cross-sectional study. BMC Cancer 2010, 10: 453.

20. Kruk A, Książek J. Zmęczenie kancerozależne u chorych hospitalizowanych z powodu raka płuca. Problemy Pielęgniarstwa 2007; 15: 229 234.

21. Walsh K, Schub T. Breast cancer: treatment- and disease-related fatigue. Cinahl Information System 2011.

22. Goedendorp MM, Gielissen MFM, Verhagen CAH, et al. Severe fatigue and related factors in cancer patients before the initiation of treatment. Br J Cancer 2008; 99: 1408-1414.

23. Berger AM, Kuhn BR, Farr LA, et al. Behavioral therapy intervention trial to improve sleep quality and cancer-related fatigue. Psychooncology 2009; 18: 634-646

24. Smets EM, Garssen B, Cull A, de Haes JC. Application of the multidimensional fatigue inventory (MFI-20) in cancer patients receiving radiotherapy. Br J Cancer 1996; 73: 241-245.

25. Wang XS. Pathophysiology of cancer-related fatigue. Clin J Oncol Nurs 2008; 12 (Suppl. 5): 11-20.

26. Reif K, de Vries U, Petermann F, et al. Chronische Fatigue bei Krebspatienten. Medizinische Klinik 2010; 105: 779-786.

27. Scott JA, Lasch KE, Barsevick AM, Piault-Louis E. Patient's experiences with cancer-related fatigue: a review and synthesis of qualiative research. Oncol Nurs Forum 2011; 38: E191-E203.

28. Minton O, Stone PC. The use of proteomics as a research methodology for studying cancer-related fatigue: a review. Palliat Med 2010; 24 : 310-316.

29. Fluge $\varnothing$, Mella O. Clinical impact of B-cell depletion with the anti-CD20 antibody rituximab in chronic fatigue syndrome: a preliminary case series. BMC Neurology 2009, 9: 28.

30. Van Der Lee ML, Garssen B. Mindfulness-based cognitive therapy reduces chronic cancer-related fatigue: a treatment study. Psychooncology 2012; 21: 264-272.

31. Núñez M, Fernández-Solà J, Nuñez E, et al. Health-related quality of life in patients with chronic fatigue syndrome: group cognitive behavioural therapy and graded exercise versus usual treatment. A randomized controlled trial with 1 year of follow-up. Clin Rheumatol 2011; 30: 381-389.

32. Krzemieniecki K. Leczenie wspomagające $u$ chorych na raka gruczołu krokowego. Termedia, Poznań 2008.

33. Racciatti D, Gorgoretti V, Sepede G, et al. An Italian study on healthrelated quality of life and fatigue in patients with chronic fatigue syndrome and patients with chronic HCV virus infection: similarities and differences. Int J Immunopathol Pharmacol 2011; 24: 673-681.

34. Hong P, Li J. Lack of evidence for a role of xenotropic murine leukemia virus-related virus in the pathogenesis of prostate cancer and/or chronic fatigue syndrome. Virus Res 2012; 167: 1-7.

35. Buss T. Problem zmęczenia u pacjentów pozostających pod opieką hospicyjną w aspekcie kliniczno-terapeutycznym. Akademia Medyczna w Gdańsku, Gdańsk 2006. 